\title{
POLICY POSITIONING IN THE EUROPEAN PARLIAMENT*
}

\author{
Gail McElroy \\ Trinity College Dublin
}

\author{
Kenneth Benoit \\ London School of Economics
}

10 February 2011

\begin{abstract}
Party politics in the European Parliament consists of competition between transnational party groups, each consisting of multiple national member parties from the EU's 27 member states. Characterizing the policy space that these parties inhabit and their ideological positions is both practically and conceptually challenging. In this paper we characterize this policy competition by tracking EP political groups from three separate, original expert surveys taken in 2004, 2007, and 2010. We look at the relative positioning of the groups on multiple dimensions of policy, as well as changes in party group policy since 2004. Additionally, we characterize the policy cohesion of party groups by examining the relative positions of each group's constituent parties, using independent national level expert surveys. The results reinforce previous findings that EP party groups not only occupy the entire range of the left-right spectrum, but also are clearly distinguishable from one another in policy terms. Moreover, their national party makeup consists of parties that are broadly cohesive in terms of their policy locations.
\end{abstract}

Key Words: Party Competition, Policy Positions, European Parliament, Expert Surveys.

Word count: 5,670 (Text, Footnotes and References)

5,973 (Text, Footnotes, References, Tables and Figures)

8,178 (Including Appendices, which will be made available online).

\footnotetext{
* Originally presented at the closing PIREDEU conference, Brussels, November 18-19, 2010. Support for this project was provided by the Irish Research Council for Humanities and Social Sciences/European Science Foundation and the Institute for International Integration Studies, Trinity College, Dublin. We thank Darren Caulfield, Marina McGale and Sander Ensink for research support. Lead author contact information: Department of Political Science, Trinity College, Dublin 2, Ireland; e-mail mcelroy@tcd.ie.
} 
As the European Parliament (EP) has expanded in size and power, its political groups have grown in importance. Unlike the national political parties that they comprise, however, EP party groups consist not of legislators elected directly as party group members, but rather of collections of affiliated MEPs elected as members of distinct national parties. The resulting need for MEPs to answer to both national-level and EPlevel principals gives rise to a dual agent problem, and the associated difficulties of maintaining discipline and cohesion within the party groups have been subject to recent study (Hix, Noury and Roland 2007; Meserve et al 2009; Raunio 1997; McElroy and Benoit 2010). The difficulty in maintaining cohesion is further exacerbated by the very dynamic nature of party competition in the 27 member states where parties enter and exit the political arena in response to changing national conditions.

This dynamism in policy competition at the national level directly affects EP party groups. Over time, party groups split and merge, some cease to exist, and new ones are created. In addition, national party members as well as individual MEPs may switch affiliations in between elections. Not just at European elections therefore, but also in between elections, party groups must formulate and reformulate their policy positions on a number of political dimensions. Much of this policy positioning is to attract additional national parties into the ranks of EP groups, but it also serves to represent the party group directly to the European electorate, and to guide its stance on the legislative issues that arise in the Parliament.

A key question that arises for students of the European Union therefore is how best to locate EP party groups in policy space, and what this means both conceptually and practically. Placing parties in policy space has long formed a challenging measurement problem for political researchers in general, because one can never 
know directly and objectively what are the dimensions, the metrics, and the correct measurement tools (see Benoit and Laver 2006). Locating EP party groups, poses an even greater challenge due to their multi-party character and the particularly dynamic environment in which they operate (McElroy and Benoit 2007). It is our contention that as expert surveys take into account many aspects of party policy, they offer a good means for measuring the policy positioning of European party groups. Expert surveys do not suffer the limitations of manifesto-based measures that are limited by the fact that not all political groups issue Euromanifestos. Expert surveys also tend to be much more informed than measures based on mass opinion surveys - indeed, so few European voters are familiar with EP party groups that the standard placement question is not even asked in European election surveys. ${ }^{1}$

In this paper, we apply expert survey methodologies to update the McElroy and Benoit (2007) measures of EP party group policy positions taken in 2004. Our update covers the mid-term of the $6^{\text {th }}$ legislative session (2007), as well as the first period of the $7^{\text {th }}$ Legislature (early 2010). More particularly, this paper explores the extent to which party competition in the EP has changed in recent years following enlargement and Treaty changes. The paper proceeds as follows: First, we outline the partisan structure of the European Parliament and the process by which political groups form and evolve, and trace the main changes in political groups that have taken place over the course of the period under investigation and outline why we should expect change in the period 2004-2010. Next, we report estimates of EP party group policy positions using two new and previously unpublished expert surveys, one taken during the middle of the 6th Parliament, and one taken nine months after the elections of 2009.

\footnotetext{
${ }^{1}$ One further alternative is to weight the voter positioning of all of the national parties that make up a group to arrive at a measure of policy position using, for example, European Election Study data (Gschwend et al 2010). But this approach is very indirect and as we demonstrate later in the paper, political groups are more than the weighted sum of their parts.
} 
We then profile the diversity of national party members in each party group using the most recent national-level expert survey estimates of party policy. Finally, we conclude with a general discussion of the results.

\section{THE PARTISAN STRUCTURE OF THE EUROPEAN PARLIAMENT}

Party politics in the European Union is characterized by competition at two different levels. At the national level, political parties contest national, regional and local elections. At a transnational level, national parties also compete in elections for seats in the European Parliament (EP). National political parties remain the basic organizational unit for both the national and European elections, controlling access to ballots, representing policy, and organizing election campaigns. National political parties also form the primary constituent units of the party groups in the EP, coming together to form transnational political entities. Political groups comprise multiple national level political parties, with as many as 45 separate national parties coming together to form an official Group.

Over the course of the European Parliament's history there has been a considerable degree of fluidity in the party system within the Parliament. National parties frequently change their affiliations, and both EP party groups and national parties come and go, change their names and also their policy positions over time. In total, more than twenty political groups have existed between 1979 and 2010, with upwards of ten groups at any one time. Appendix A lists all the political groups that have existed since the Parliament's foundation. Some of the groups have been relatively short-lived (e.g. Identity, Sovereignty and Tradition [ITS] which lasted a mere ten months), while others have been merely heterogeneous collections of national parties that formed in order to be eligible for the benefits of group 
membership (such as speaking time and committee chairs). In addition to changes in the party groups themselves, national parties also switch affiliation between existing groups. This type of switching is often motivated by factors internal to the European Parliament, such as disagreements over policy or the spoils of parliamentary office.

Despite such fluidity in the party system of the European Parliament, the main party groups have become increasingly cohesive and powerful over time (Raunio, 1997; Hix, Noury and Roland 2007). Levels of voting cohesion have been rising across parliamentary sessions, especially for the three largest political groups, notwithstanding increases in the overall size of the EP (from its original 142 MEPs to its current 735) and the number of member states. We thus have an interesting juxtaposition of high membership turnover in the EP of both individual MEPs and national parties with the continued institutionalization of the political groups built around national parties and their MEPs.

There are numerous reasons to expect changes during the period 2004-2010 in both the positions and number of the political groups and the principal policy dimensions on which these groups compete. First, the EU expanded significantly in this period with two rounds of enlargements to the east. The European Parliament increased in size by over a quarter from 626 members to (temporarily) 785 members. These new members constitute 27 percent of the current 735 elected representatives. This sudden increase in numbers may have acted as a realigning shock to the system, especially when one considers that the new members are from party systems that are not fully institutionalized and in which the old social cleavages of Western European do not neatly apply.

Second, the period also witnessed a significant rise in the number of Euroskeptic MEPs. Once seen as a fringe grouping, Euroskeptic MEPs have moved 
centre stage, reflecting a general rise in Euroskepticism in the member states of the EU (de Vries and Edwards 2009). All of the member states now have some form of Euroskeptic party competing in European elections. In the 2009 elections, the far right also won substantial support in some member states where they were not traditionally strong, for example the Netherlands, Austria, Denmark, Finland and the United Kingdom. This strengthening of the right and far right should have an impact on the axes of competition in the EP, given both groupings are strongly Euroskeptic and socially conservative.

Third and more generally, electoral volatility at the national level and the associated party system change and fragmentation should be reflected in the number and nature of parties elected to the EP. The vote shares of established and incumbent parties dropped in many member states across the last decade. In Germany, for instance, the share of the vote of the main parties has dropped from the traditional 75 percent plus to less than 68 percent. This volatility is only magnified at the European elections. An extraordinary 45 percent of all national parties represented in the European Parliament in May 2004 were not represented in the post-2009 European Parliament. This level of turnover and volatility can be expected to impact party competition within the EP itself.

Finally, EU Treaty changes may have had some impact on internal EP party competition. The passage of the Lisbon Treaty (anticipation and eventual ratification) had a significant impact on the internal legislative processes of the European Parliament. The co-decision (now ordinary legislative) procedure was extended to nearly 50 new areas of policy increasing the powers of the EP in a host of key areas such as asylum, the common agricultural policy and policies relating to the 'general economic interest'. We should expect these issue areas to become more important in 
internal parliamentary politics as a result. For instance, given the redistributive nature of the CAP and the contested question of immigration, we might expect the salience of these issue areas to increase now that the EP is a veto player in these policy areas.

On the other hand, the balance of power in the EP has remained constant over the course of the past decade. The European People's Party (EPP) wrested control of the top spot from the Party of European Socialists (PES) in 1999 and has not relinquished it in subsequent elections, with its overall share of seats remaining surprisingly constant at around 36 percent. The second largest group, the Socialists have seen their overall share of seats drop slightly from 28 percent to 25 percent but they are still far larger than the Liberal grouping, whose share of seats, while increasingly slightly, still places them firmly in a distant third position, though potentially holding the balance of power (Hix and Noury 2009). This element of stability and continuity in political groups may dampen the impact of any of the realigning factors outlined above.

\section{PARTY GROUPS IN THE 2009-ELECTED PARLIAMENT}

The immediate post election period in the European Parliament is generally a time of change and the 2009 election was no different. Two new political groups were formed, over fifty of the national parties represented in the previous legislature failed to elect any MEPs, and almost seventy new national parties gained representation. In this section, we briefly outline the major changes that took place and provide an overview of the relative size of each group.

The dissolution of the Union for a Europe of Nations (UEN) grouping in 2009 was one of the more notable features of the post election realignment. The UEN had been in existence in one form or another since 1994 but was not reconstituted after the 
2009 elections. The largest national party within the UEN, the Italian National Alliance, had merged at the domestic level with Berlusconi's Forza Italia in March 2009 to form the People of Freedom and stuck with Forza Italia's prior affiliation with the EPP. Another key player in the group, Ireland's Fianna Fail, had long been looking for an alternative group to join as it was uncomfortable with the Euroskeptic profile of UEN and took the opportunity to join the Liberals.

The disappearance of the UEN had repercussions for the Independence/Democracy Group (iD), as it was one of the main suitors for those parties of the UEN left homeless. Lega Nord, Order and Justice (Lithuania) and the Danish People's Party launched the new Europe of Freedom and Democracy (EFD) group with what was left of iD after the election. The remaining national parties from the UEN, For Fatherland and Freedom (Latvia), Law and Justice (Poland) and Christian Union (Netherlands) joined the other new Euroskeptic political group in the EP, the European Conservative and Reformists Group (ECR). This latter group was spearheaded by the British Conservative Party, which left the European People's Party after many tense years,. This new group is based on conservative values and a shared belief in a non-federal Europe.

\section{[Table 1 about here]}

Table 1 summarizes the composition of the political groups at the time of our two new expert surveys, in October 2007 and April 2010. In both periods the European People's Party was the largest group with over 35 percent of the seats. The Party of European Socialists (renamed the Group of Socialists \& Democrats in 2009) maintained a steady state also with around a quarter of the total seats in both 2007 and 2010. The Liberals (ALDE) experienced a temporary boost in numbers with the accession of Bulgaria and Romania in early 2007 and while their overall percent of 
seats marginally decreased in the 2009 elections, it was in line with their 2004 election seat share. The Greens experienced a significant boost in the elections, increasing their presence from 5.5 percent to over 7 percent and are now ranked as the fourth largest group in the EP, despite once again failing to win any seats from the 12 newest member states in the 2009 elections.

It can be seen from Table 1 that the election of 2009 did not radically affect the general balance of power in the European Parliament. With the exception of the demise of the UEN and creation of the new ECR Group, the party systems of 2007 and 2009 are rather similar to that of 2004. It bears repeating, however, that the aggregate numbers do hide a significant amount of change within the party groups themselves which may be reflected in overall group policy positions as well as the importance they place on particular policy dimensions.

\section{UPDATING THE EXPERT SURVEYS OF EP POLICY POSITIONS}

Our expert survey methodology applied in 2007 and 2010 followed the same basic procedure as McElroy and Benoit (2007). After updating our list of academic experts on the European Parliament, we sent individual invitation emails containing a link to the web-based, English-language survey questionnaire. Approximately three weeks later, a follow-up email was sent reminding experts to participate had they not yet done so. In all, for the 2007 survey we received 25 responses based on 68 invitations, for a response rate of 37 percent. In the 2010 survey, we received 19 responses from 42 invitations, for a response rate of 45 percent. These compared to a $67 \%$ response rate from the 2004 exercise which solicited 36 experts.

The only substantive changes we made to the survey questionnaire concerned the updating of the party groups to be located, and the addition of a dimension related 
to decentralization policy that had been omitted from the 2004 questionnaire. This dimension was worded as follows:

\section{Decentralization/Subsidiarity}

Insists on the subsidiarity principle in all administration and decision-making. (1) Accepts more centralized EU-level administration and decision-making. (20)

\section{RESULTS FROM THE EXPERT SURVEYS}

\section{Left-Right Positioning}

A full statistical summary of the 2010 results of the expert locations of the party groups on each policy dimension is presented in Appendix B. ${ }^{2}$ Figure 1 portrays the differences in left-right positions from the 2010 survey, along with $95 \%$ confidence intervals.

\section{[Figure 1 about here]}

At the far left of the political spectrum is the European United Left/Nordic Green Left (GUE/NGL), with a mean value of 2.9 (95\% CI: $2.3,3.5)$, followed by the Greens $(\mathrm{Gr} / \mathrm{EFA})$ at $4.4(3.7,5.1)$. The three largest party groups, the Socialists (S\&D), the Liberals (ALDE), and the European People's Party (EPP) occupied positions on the left-of-center, center, and right-of-center at $7.8(7.2,8.4), 11.9(11$, $12.7)$, and $13.5(12.9,14.2)$ respectively. On the far right of the policy scale, we see the newly formed or reformed groups European Conservative and Reformist Group (ECR) and Europe of Freedom and Democracy (EFD), scoring $17.1(16.3,17.9)$ and $18.6(17.9,19.4)$ respectively.

The positioning and ordering of these main groupings is completely consistent with the 2004 survey results reported in McElroy and Benoit (2007), although the ECR and EFD are new incarnations of right-leaning party groups that did not exist in

\footnotetext{
${ }^{2}$ The table of results from the 2007 survey, datasets of both surveys, and the full survey questionnaires are available from a web-based appendix located at http://anonymous.
} 
earlier surveys. In addition, each group's position is statistically distinguishable from the positions of its neighbors, based on the $95 \%$ confidence intervals. Party groups not only span the entire left-right policy spectrum in the EP, but also occupy regions of the left-right policy space that are distinct from one another.

\section{Policy Positioning in Two Dimensions}

Policy positioning in the European Parliament is at least two-dimensional, it has been argued (Hix and Lord 1997; Gabel and Hix, 2004; McElroy and Benoit 2007), consisting of a dimension of left-right policy as well as relative preferences concerning the scope and character of further European integration. In national political settings, Benoit and Laver (2006) demonstrated that nearly all political competition can be plausibly placed on two separable dimensions of policy, one related to economic left-right, and a second related to social liberalism versus moral conservatism. In Figures 2 and 3, we plot the two-dimensional positions of the main party groups on both pairs of dimensions, tracking their positioning over time across the 2004, 2007, and 2010 surveys. Here we have abstracted the precise groupings into their broad categories, such that the "Liberal" grouping (for example) consists of the ELDR in 2004, and ALDE from 2007-2010. ${ }^{3}$

\section{[Figure 2 about here]}

Figure 2 contrasts party group positions on two "standard" dimensions of economic left-right, represented by attitudes toward the regulation of markets, and social liberalism versus moral conservatism. ${ }^{4}$ Broadly speaking, the alignment of

\footnotetext{
${ }^{3}$ The precise equivalencies are as follows. Left: GUE/NGL; Green: Gr/EFA and Verts (2004); Socialist: PSE/PES (2004-2007), S\&D (2010); Liberals: ALDE and ELDR (2004); Christian Democrats: EPP (2004, 2010) and EPP-ED (2007); Conservatives: ECR (2010); Right: EDD, iD, EFD. The UEN and ITS are represented as their own categories.

${ }^{4}$ The wording of these two dimensions is as follows. Deregulation: Favours high levels of regulation and control of the markets, such as telecommunications (1), versus: Favours deregulation at every opportunity (20). Social: Favours liberal policies on matters such as homosexual law, abortion, and
} 
party positions in one-dimensional, split into two broad camps of left and right. The exception is the Liberal grouping, which lies to the right on economic policy but to the left on social policy, consistent with classic liberal party positioning on these two dimensions. Interestingly, there are no party groupings in the center of the space, and the two large clusters contain different party groups that are quite close to one another. On the right, the Christian Democratic grouping is more centrist than the UEN, the Conservative, or the Right groups, but only by a few points on each dimension. On the left, similarly, the Socialists are more centrist than the Greens or Left groups, but not by much. Finally, the evolution of party positions over time shows remarkable stability, with only the Greens appearing to have moved significantly, and then only on the economic dimension (to the left).

\section{[Figure 3 about here]}

In Figure 3, the party groups are plotted on the two dimensions of general leftright and one of anti- versus pro- EU Authority. ${ }^{5}$ Here we see a considerably different pattern, where the classic "inverted-U" shape emerges from mapping support for EU integration onto left-right positioning (Hooghe and Marks 2002). Party groups on both extremes are less favorable to continued expansion of the scope of EU authority, versus more centrist parties. While the Right, Conservative, and UEN groups are highly Euroskeptic as expected, we also see the Left as not only Euroskeptic, but also becoming increasingly so with each survey. Despite also having a pro-environmental component, the GUE/NGL's position on the European policy dimension also clearly distinguishes it from the main Green grouping.

euthanasia (1), versus: Opposes liberal policies on matters such as homosexual law, abortion, and euthanasia (20).

${ }^{5}$ Here the question wording was: EU Authority: Favours increasing the range of areas in which the EU can set policy (1), versus: Favours reducing the range of areas in which the EU can set policy (20). In Figure 3, the scale is inverted so that 1 represents the anti-EU position. 


\section{[Figure 4a,b about here]}

Policy Change from 2004 to 2010

The analyses in two dimensions also suggested that movement of party groups in policy space was rather limited. To examine the question of change in more detail, we have compared the positioning of our broad groupings from 2004 to 2010 . Figures $4 \mathrm{a}$ and $4 \mathrm{~b}$ plot the change along each dimension of the major groupings, along with a 95\% confidence interval for the change shown by the lines overlaid on each bar.

When the capped line overlaps the origin, it means that the change cannot be distinguished statistically. The results reinforce some of our earlier interpretations. On the question of EU Authority, the Greens became more Euroskeptic (with the positive change here indicating greater skepticism for further expansion of EU authority as well as the EU Federalism dimension with regard to how the EU would be held accountable $^{6}$ ). The Greens also became more skeptical towards involving the EU in collective security missions. ${ }^{7}$ The Socialists moved slightly to the left on Deregulation policy, and the Christian Democrats were placed slightly more to the right in 2010 than they had been in 2004. Finally, on the specific issue of immigration policy ${ }^{8}$, the Socialists became more permissive, while the Christian Democratic grouping shifted slightly in the opposite direction.

All in all, the analysis shows that the positions of the major party groupings changed relatively little from 2004, with the important exceptions noted above.

\footnotetext{
${ }^{6}$ Wording: Federalism: Promotes a federal vision for the EU (1), versus: Promotes a Europe of nationstates (Europe des Patries) (20).

${ }^{7}$ The exact wording here was: Collective Security: Favours a common defence and security policy for member states (1) versus: Opposes development of common defence and security policy (20).

${ }^{8}$ The wording here was: Immigration: Favours policies designed to help asylum seekers and immigrants integrate into European society. (1) versus: Favours policies designed to restrict access of asylum seekers and immigrants to Europe (20).
} 


\section{THE RELATIVE IMPORTANCE OF POLICY DIMENSIONS}

In addition to locating the policy positions of parties on each policy dimension, experts in our surveys also indicated how important each policy dimension was for each party (with a score of 20 indicating the most important). The full set of importance scores from the 2010 survey are detailed in Appendix Table B2. To get an average depiction of the most important political issues across party groups, we have averaged the importance scores across groups, weighting by the 2010 seat share so that the overall importance average for an issue is not distorted by extreme positions held by the smaller groupings (e.g. the extreme right positions on the EU and Decentralization policy held by the relatively smaller EFD).

\section{[Figure 5 about here]}

Figure 5 plots the overall importance scores by issue. The two economic policy dimensions, not surprisingly, are foremost in importance to the parties. Second to these is the other "main" dimension of social liberalism, further supporting the view that policy positioning takes place primarily on the two dimensions of economic and social policy. While broadly consistent with the bulk of previous expert surveys of party policy in Europe (e.g. Benoit and Laver 2006), the high importance of the social dimension is rather different from the results of the 2004 expert survey of EP policy from McElroy and Benoit (2007), which placed the Social dimension last in importance. This change in emphasis may reflect the growing strength of far right and conservative parties in the EP.

A set of EU and related dimensions with international implications - EU Authority, EU Federalism, Immigration, and Collective Security - followed Social policy in importance, with the Environment and Decentralization, interestingly, following last in importance. While several parties consider these "last" dimensions as 
the most important, such as the Greens and the EFD, their smaller sizes contribute relatively less to the policy importance as a weighted average.

\section{THE POLICY COHERENCE OF PARTY GROUPS}

Recent work on the question of which political group national parties choose to affiliate with whilst in the EP suggests that the process is driven mainly by a concern to minimize policy incongruence between the national and transnational levels (McElroy and Benoit 2010). If this is the case, we should expect to observe strong similarities in policy positioning among the national parties within each EP party group. Additionally, we should expect the European political groups to be placed at the centre of the distribution of their member parties on each dimension of contestation.

\section{[Figure 6 about here]}

Figure 6 portrays the kernel density estimate of member state party positions for each EP party group on the left-right dimension, as well as the mean of the EP party group position on this dimension. Each "rug" line at the base of the plots indicates the position of a national member party. Data on the national-level placement of parties comes from the left-right positions from the expert surveys reported in Benoit and Laver (2006) and updated versions of these surveys conducted in the past five years. The graphs also indicate how many national member parties were included in each analysis (a full listing is provided in Appendix C). Several points of interest emerge from this figure. First, there is a clear correspondence between the political groups' location and the central tendency of the national parties positions for EPP and S\&D and the GUE/NGL. The former are the two largest groups and their left-right positions neatly reflect the central tendencies of their constituent parties. The Green 
group and the Liberals are more left than the central tendency of their member parties. In addition, there exist a handful of extreme outlying national parties within some groups. Within the Green group, for instance, the expert placement of the Belgian New Flemish Alliance (N-VA) was far more centrist than any other Green party member that we measured.

In terms of the overall diversity of positions with party groupings, ALDE has the widest range of positions among its member parties. Since 2004 the ALDE has actively recruited members from outside the ranks of the traditional liberal parties of Europe, notably in France, Italy and Ireland (Corbett et al 2007, 85). In fact the ALDE is purely a parliamentary construction, consisting of two separate European transnational groups, the traditional European Liberal Democratic and Reform Party and the more recently constituted European Democrat Party (EDP), though the bulk of national parties still come from within the ELDR tradition. ${ }^{9}$

The second striking pattern from Figure 6 is that the newest political groups founded in 2009, the ECR and EFD, are significantly to the right of their constituent parties in terms of their position on the left right dimension. Europe for Freedom and Democracy (EFD) appears to be particularly right of the national positions of its member parties. Interestingly, the distribution of the national parties of the EFD on the L-R dimension is bimodal, perhaps reflecting a general difficulty for experts in placing far right and populist parties on this dimension. In addition, there is a rather eclectic mix of parties that have come together to form the EFD, such as UKIP and the Danish People's Party. The latter is best conceived of as a populist, rather than a traditionally right wing party and is strongly committed to social programmes such as

\footnotetext{
${ }^{9}$ Notable EDP parties include: Mouvement démocrate (France) and Partido Nacionalista Vasco (Spain).
} 
pensions and benefits for senior citizens and better services for the disabled. UKIP, on the other hand, was founded as a single-issue party, dedicated to the UK's withdrawal from the EU. Its economic policies are less well defined but they advocate lower taxes (and levels of redistribution) in general. Within the European Parliament, the EFD is principally defined by its opposition to European integration and is less concerned about economic issues. Both these political groups (EFD and ECR) are more centrist, in terms of their member parties, if we examine their positions in term of the EU authority dimension, their raison d'être.

\section{CONCLUDING REMARKS}

Our updated analysis of the policy positions of European party groupings provides new empirical material on which to assess party and policy competition in the changing European parliament. Using new and previously unpublished expert surveys from 2007 and 2010, our spatial location of the EP party groups shows that not only do party groups span the broad left-right spectrum, but also occupy positions in that space that are clearly distinct from one another. In broad left-right terms, party groups range from far left to far right. On more specific dimensions of economic and social policy, party groups broadly occupy two opposed camps, one on the left and another on the right, with few located in between. An exception is the ALDE liberal grouping, located right on economic policy but left on social conservatism.

Party groups are also distinguished from one another on policy towards further European integration and expanding the scope and authority of EU-level institutions. Our analysis confirms the "inverted-U" shaped analysis found in previous studies of the link between left-right positioning and support for European integration. It also 
suggests important differences between party groups on the issue of European integration, differences that warrant further investigation.

In comparing the relative importance of policy dimensions to European party groups, our study found results consistent with previous studies (McElroy and Benoit 2007) indicating that the economic dimension was foremost in importance, with environmental policy near the bottom of the list. The exception was the shift in importance of social policy, formerly measured at the bottom of average importance in McElroy and Benoit (2007).

Finally, in order to examine the policy cohesiveness of the party groups in 2010, we also looked at the relationship between the policy positions of the EP party groups with those of their national member parties. We found that while the experts placed the main EP political group policy positions at the centre of the distribution of the positions of their member parties, there were important exceptions. Especially with regard to the more extreme "right" party groups such as the ECR and the EFD, the expert locations of the party groups seemed to be more extreme than the typical national member party's position. In general, party groups in the European Parliament tend to consist of parties with similar, but by no means identical, policy positions on the single general dimension of left-right. The diversity of members in some significant groups such as ALDE and the EPP indicates that member parties are far from homogeneous when it comes to their policy positions, and further investigation into more specific dimensions of policy only reinforces this view. Given recent work on the difficulty of maintaining policy cohesion among party groups of diverse and dynamic member parties, the question of policy diversity and group cohesion suggests intriguing possibilities for further research. 


\section{REFERENCES}

Benoit, Kenneth and Michael Laver. 2006. Party Policy in Modern Democracies. London: Routledge.

Corbett, Richard, Francis Jacobs, and Michael Shackleton. 2007. The European Parliament, $7^{\text {th }}$ ed. London: John Harper.

De Vries, Catherine and Erica Edwards .2009. Taking Europe To Its Extremes: Extremist Parties and Public Euroscepticism. Party Politics 15(1): 5-28.

Gabel. M and Simon Hix. 2004. Defining the EU Political Space: an Empirical Study of the European Election Manifestos. In Gary Marks and M. Steenbergen, European Integration and Political Conflict. Cambridge: Cambridge University Press.

Gschwend, Thomas, James Lo and Sven-Oliver Proksch. 2010. Europe's Common Ideological Space. Paper Presented at the final PIREDEU conference, Brussels, Nov 18-19.

Hix, Simon and Christopher Lord. 1997. Political Parties in the European Union. Basingstoke: Macmillan.

Hix, Simon, Noury, Abdul and Roland, Gérard. 2007. Democratic Politics in the European Parliament. Cambridge: Cambridge University Press.

Hooghe, L and Marks, G. 2002. 'Does Left/Right Structure Party Positions on European Integration’. Comparative Political Studies vol. 35 no. 8 965-989.

McElroy, Gail, and Kenneth Benoit. 2007. "Party Groups and Policy Positions in the European Parliament." Party Politics 13: 5-28.

McElroy, Gail, and Kenneth Benoit. 2010. "Party Policy and Group Affiliation in the European Parliament”, British Journal of Political Science. 40, (2), 2010, p377 398.

Meserve, Stephen, Daniel Pemstein and William Bernhard. 2009. "Political Ambition and Legislative Behavior in the European Parliament." Journal of Politics 71 (3): $1015-1032$

Raunio, T. 1997. The European Perspective: Transnational Party Groups in the 1989-1994 European Parliament. Aldershot: Ashgate. 


\begin{tabular}{|c|c|c|c|c|c|}
\hline EP Party Group & Label & $\begin{array}{r}\text { Seat } \% \\
2007 \\
\end{array}$ & $\begin{array}{r}\text { Seats } \\
2007 \\
\end{array}$ & Seat \% 2010 & Seats 2010 \\
\hline European People's Party & EPP & 35.4 & 278 & 36.0 & 265 \\
\hline Party of the European Socialists/Socialists and Democrats & PES/S\&D & 27.5 & 216 & 24.9 & 183 \\
\hline \multicolumn{6}{|l|}{ Alliance of Liberals and Democrats for Europe } \\
\hline & ALDE & 13.2 & 104 & 11.6 & 85 \\
\hline European United Left/Nordic Green Left & GUE/NGL & 5.2 & 41 & 4.8 & 35 \\
\hline Greens/European Free Alliance & Verts/EFA & 5.4 & 42 & 7.5 & 55 \\
\hline Union for a Europe of the Nations & UEN & 5.6 & 44 & & \\
\hline Independence/Democracy Group & $i \mathrm{D}$ & 3.1 & 24 & & \\
\hline Identity Tradition and Sovereignty Group & ITS & 2.9 & 23 & & \\
\hline Europe of Freedom and Democracy & EFD & & & 4.1 & 30 \\
\hline European Conservative and Reformist Group & ECR & & & 7.3 & 54 \\
\hline Non Affiliated & $\mathrm{NI}$ & 1.7 & 13 & 3.8 & 28 \\
\hline Total & & 100 & 785 & 100 & 735 \\
\hline
\end{tabular}

Table 1. Political Party Groups in European Parliament at the times of the two expert surveys, 2007 and 2010.

Source: European Parliament official website 


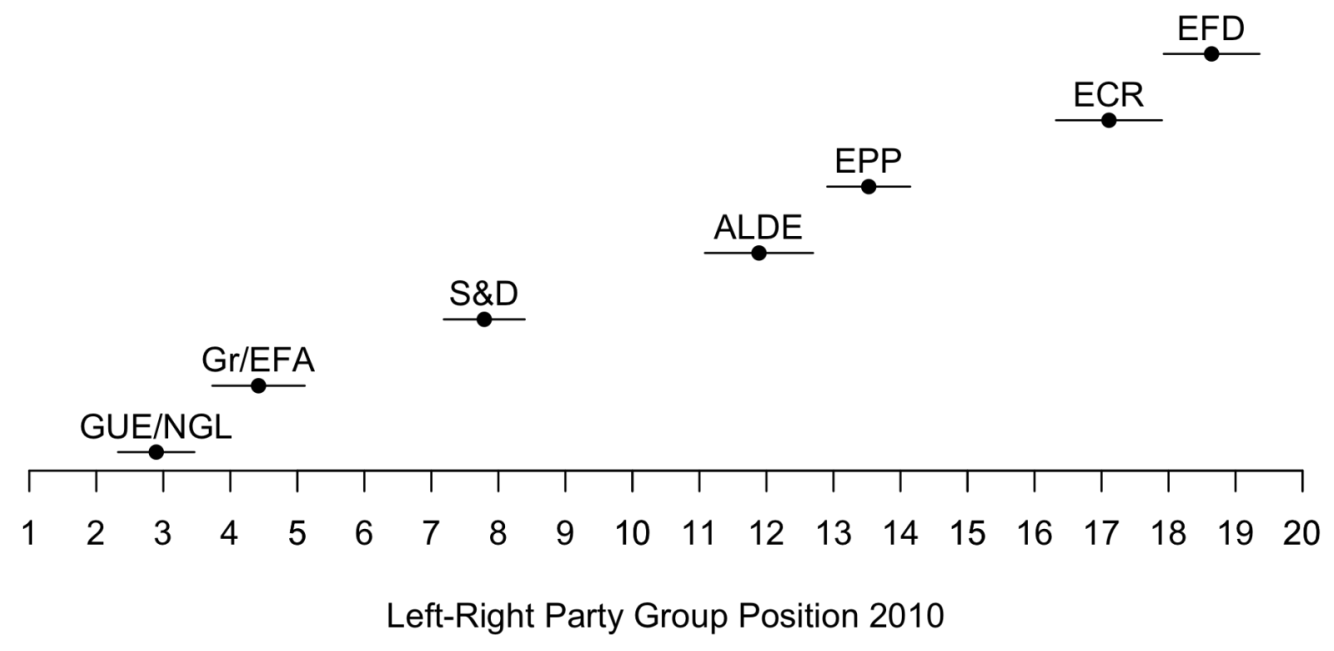

igure 1. European Party Groups on the General Left-Right Scale. 


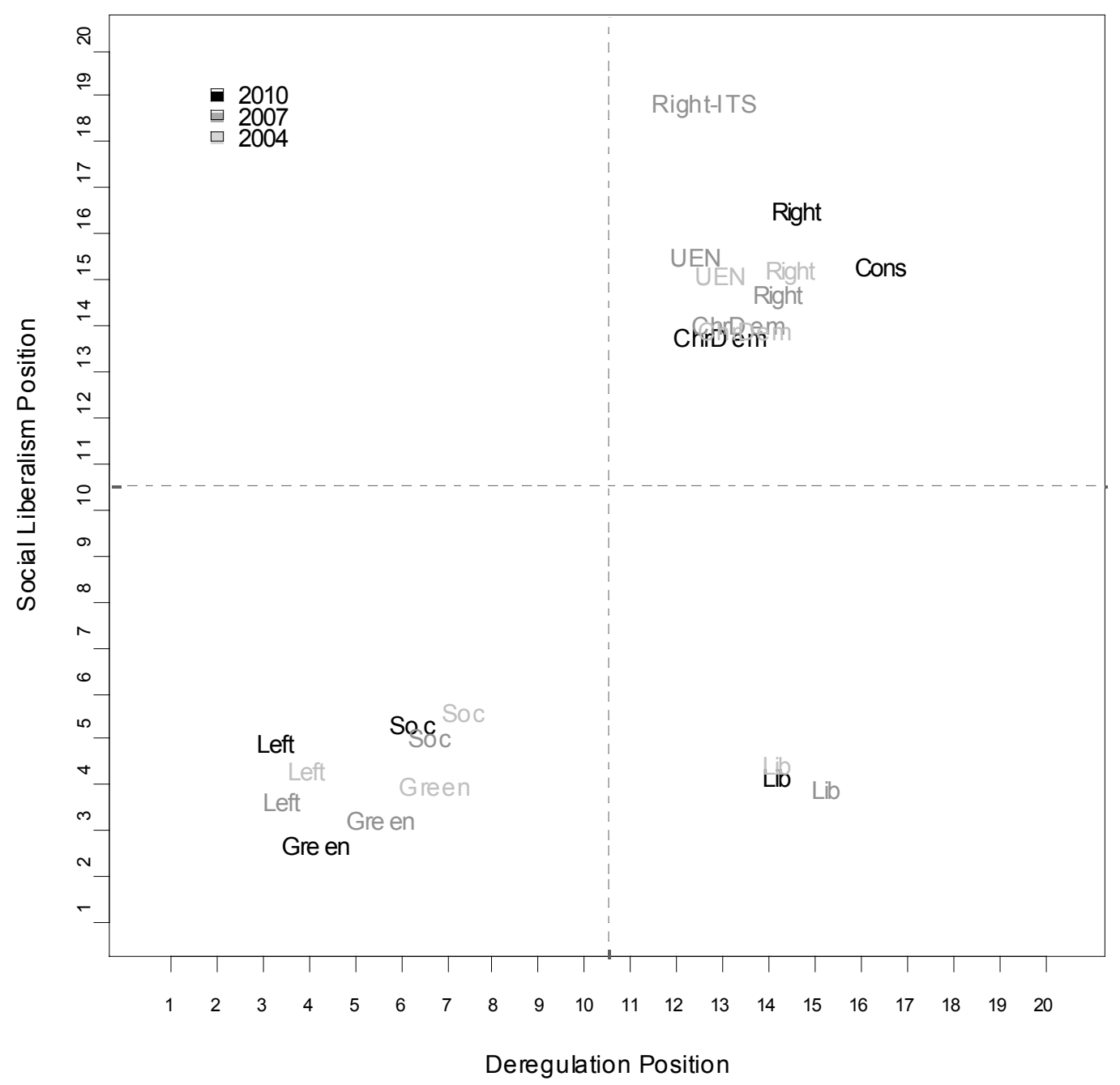

Figure 2. EP Party Group Positioning on the Economic versus Social Policy

Dimensions. The labels refer to: Left - GUE/NGL; Green - Greens/EFA, Verts; Soc - PSE, S\&D; Lib - ELDR, ALDE; ChrDem - EPP, EPP-ED; Cons - ECR; Right - EDD, iD, EFD; UEN - UEN; ITS-ITS. 


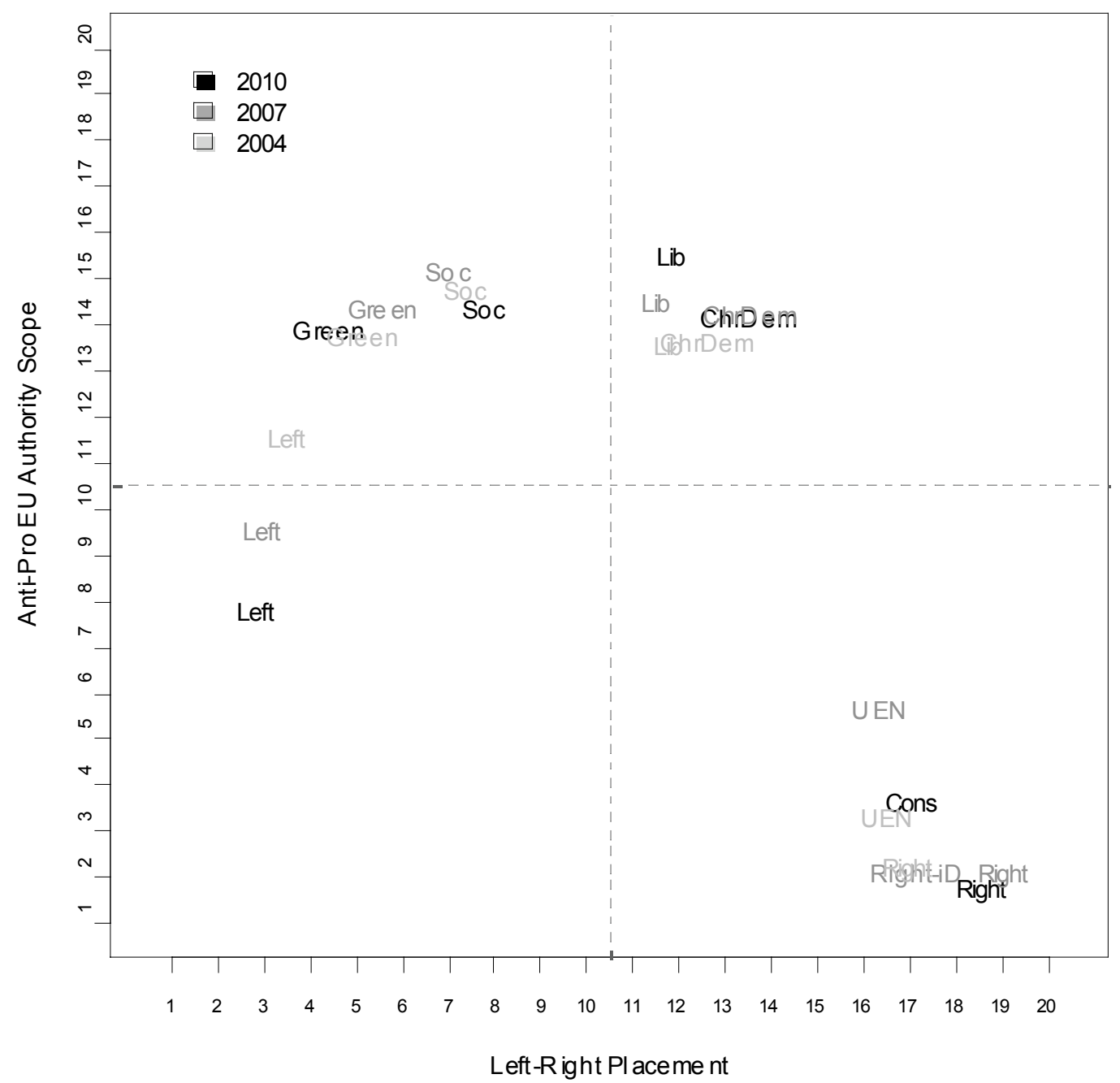

Figure 3. EP Party Group Positioning on the Left-Right versus European Policy Dimensions. 
Economic (Spending v. Taxes)

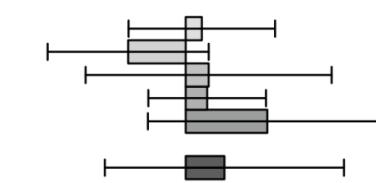

UEN

Environment

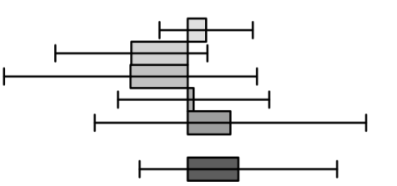

Soc

$\square$ Green

$\square$ Left

$\square$ ChrDem

$\square$ Right

$\square$ Cons

$\square$ Lib

EU: Authority
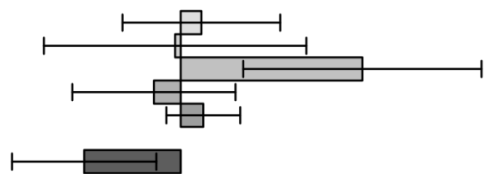

Deregulation

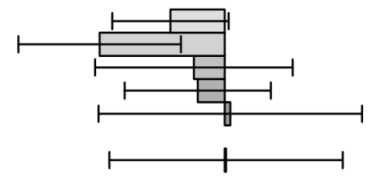

Collective Security

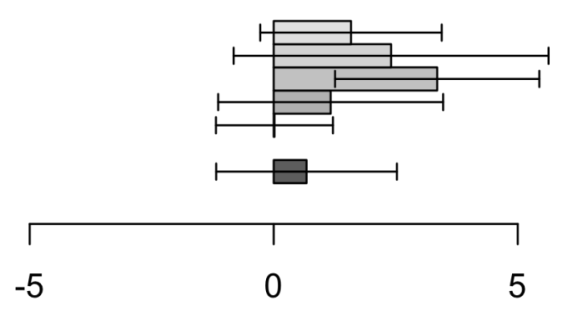

Movement from 2004 to 2010

Figure 4a. Movement from 2004 to 2010 on Constituent Policy Scales for Broad Categories of EP Grouping. Bars indicate $95 \%$ confidence intervals. 


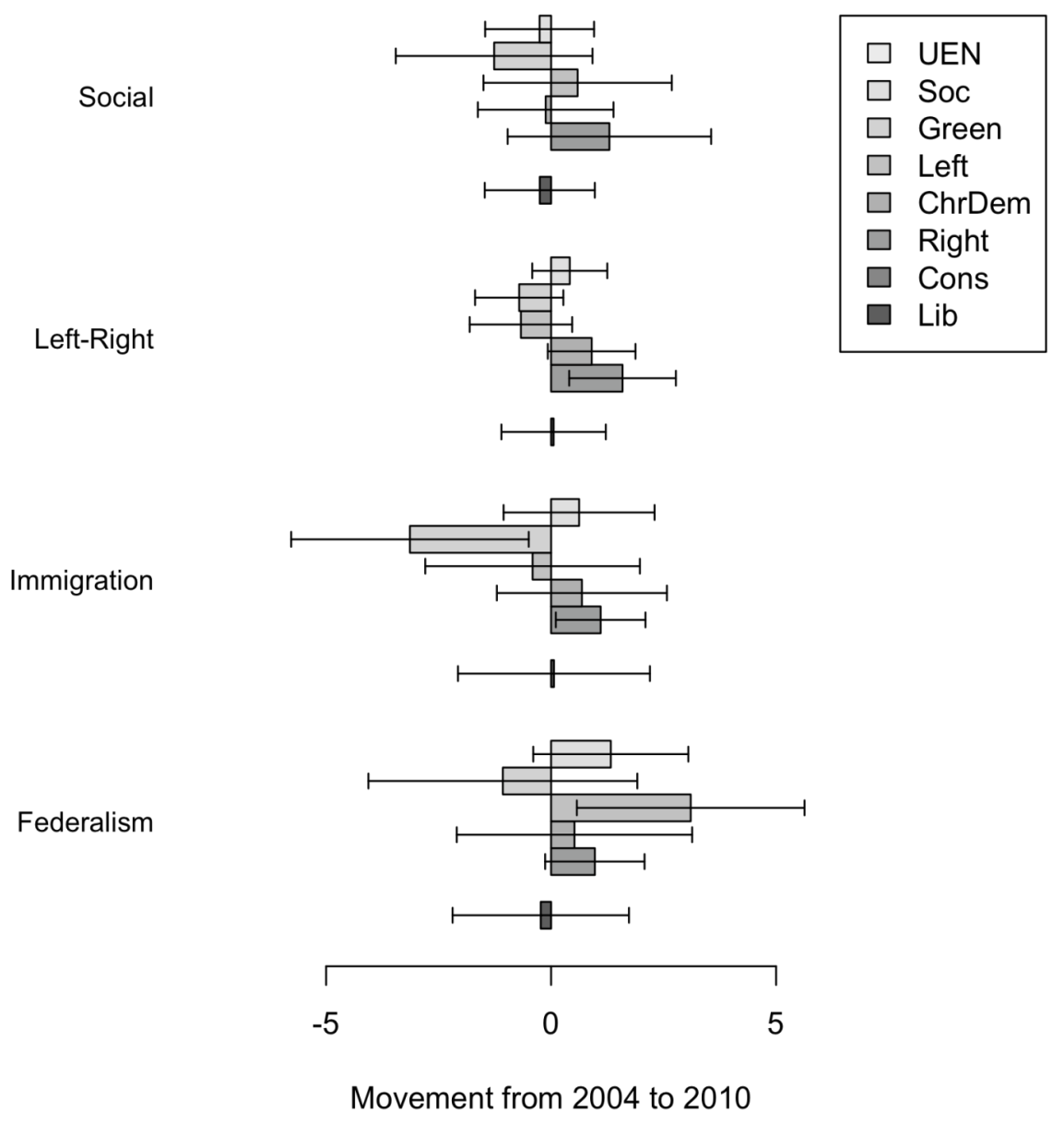

Figure 4b. Movement from 2004 to 2010 on Constituent Policy Scales for Broad Categories of EP Grouping. Bars indicate $95 \%$ confidence intervals. 


Eco nomic (Sp ending v. Taxes)
D ere gulation
So cial
EU : Authority
F ederalism
Immi gra tion
Collective Security
En vironment
D ecentralization/Subsidiarity

Figure 5. Overall Importance of Policy Dimensions, 2010. Means averaged across party groups, weighted by seat shares. 

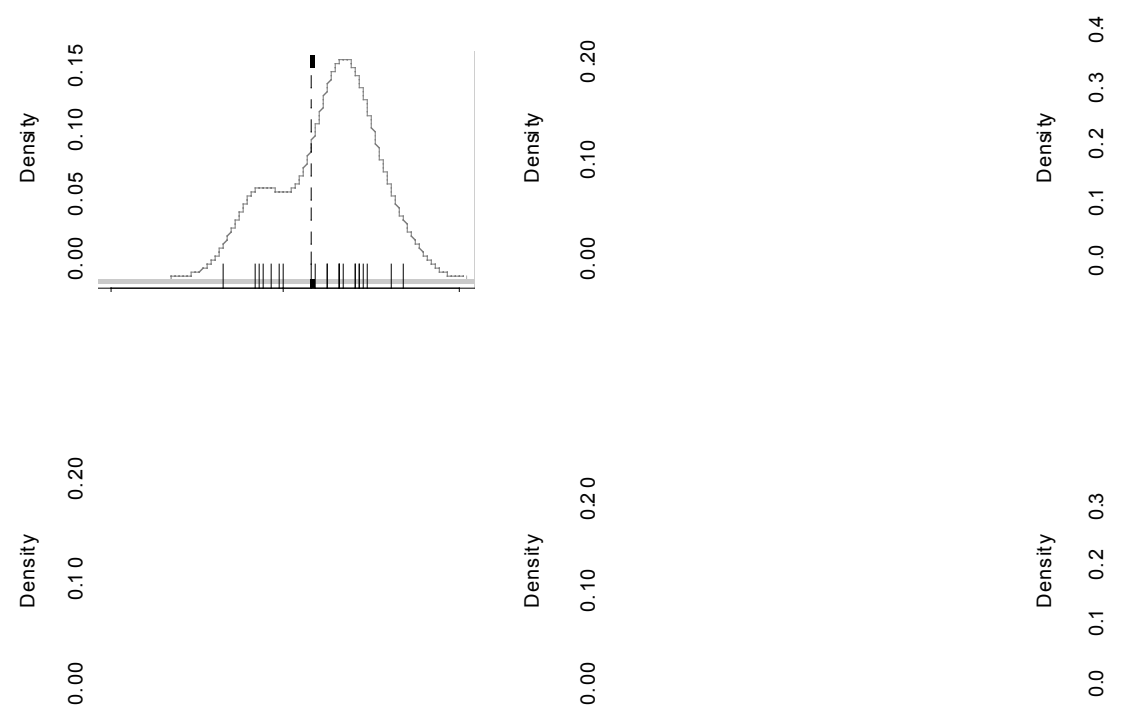

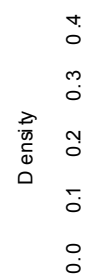

Figure 6. EP Party Group Positions and the Distribution of National Member Parties, Left-Right Scores.

Source: Benoit and Laver (2006) as well as updated unpublished expert survey data (surveys from 2006-2010) for national party left-right scores. 
Appendix A: Full List of Political Groups in EP, 1957-2010

\begin{tabular}{|c|c|c|c|c|c|}
\hline Name & Abbreviation & $\begin{array}{l}\text { Abbrev. } \\
\text { equivalencies }\end{array}$ & Formed & Dissolved & Notes \\
\hline $\begin{array}{l}\text { European People's } \\
\text { Party }\end{array}$ & EPP & CD/ PPE app. & 1953 & Present & $\begin{array}{l}\text { Christian Democratic Group } \\
\text { (CD) until } 1979\end{array}$ \\
\hline $\begin{array}{l}\text { Party of European } \\
\text { Socialists }\end{array}$ & S\&D & S/PES & 1953 & Present & $\begin{array}{l}\text { Socialist Group until 1993, } \\
\text { Socialists and Democrats } \\
\text { from } 2009\end{array}$ \\
\hline $\begin{array}{l}\text { Alliance of Liberals } \\
\text { and Democrats for } \\
\text { Europe }\end{array}$ & ALDE & $\begin{array}{l}\text { ELDR/L } \\
\text { LDR }\end{array}$ & 1953 & Present & $\begin{array}{l}\text { Liberal Group/Liberal and } \\
\text { Democratic Group } \\
\text { (1976)/Liberal Democratic } \\
\text { and Reformist Group } \\
\text { (1986)/ALDE (2004) }\end{array}$ \\
\hline $\begin{array}{l}\text { European Democratic } \\
\text { Group }\end{array}$ & ED & $\mathrm{C}$ & 1973 & 1992 & $\begin{array}{l}\text { Formerly European } \\
\text { Conservatives until } 1979\end{array}$ \\
\hline $\begin{array}{l}\text { European Democratic } \\
\text { Alliance }\end{array}$ & RDE & DEP & 1965 & 1995 & $\begin{array}{l}\text { Formerly (until 1973) the } \\
\text { European Democratic } \\
\text { Union, then European } \\
\text { Progressive Democrats } \\
\text { (DEP). }\end{array}$ \\
\hline Communists & COM & & 1973 & 1989 & \\
\hline Union for Europe & UPE & & 1995 & 1999 & Alliance of FE and RDE \\
\hline European Right & DR & & 1984 & 1994 & $\begin{array}{l}\text { Forced dissolution as failure } \\
\text { to meet required numbers to } \\
\text { form a group }\end{array}$ \\
\hline Rainbow Group & ARC & & 1984 & 1994 & \\
\hline $\begin{array}{l}\text { Greens/European Free } \\
\text { Alliance }\end{array}$ & $\mathrm{V}$ & Verts/ALE & 1989 & Present & \\
\hline Left Unity & CG & & 1989 & 1994 & \\
\hline $\begin{array}{l}\text { Group for the European } \\
\text { United Left }\end{array}$ & GUE & & 1989 & 1993 & \\
\hline $\begin{array}{l}\text { European United } \\
\text { Left/Nordic Green } \\
\text { Alliance }\end{array}$ & GUE/NGL & & 1994 & Present & $\begin{array}{l}\text { Primarily based on Left } \\
\text { Unity parties and reformist } \\
\text { groups from dissolved GUE } \\
\text { that had survived } 1994 \\
\text { election. }\end{array}$ \\
\hline $\begin{array}{l}\text { European Radical } \\
\text { Alliance }\end{array}$ & ARE & & 1994 & 1999 & \\
\hline Forza Europe & FE & & 1994 & 1995 & $\begin{array}{l}\text { Merges with European } \\
\text { Democratic Alliance in } \\
1995\end{array}$ \\
\hline $\begin{array}{l}\text { Independence and } \\
\text { Democracy }\end{array}$ & iD & $\begin{array}{l}\text { IND/ DEM } \\
\text { EDD }\end{array}$ & 1999 & 2009 & $\begin{array}{l}\text { Equivalent Europe of } \\
\text { Democracies and } \\
\text { Diversities (EDD) (1999- } \\
\text { 1994) }\end{array}$ \\
\hline $\begin{array}{l}\text { Europe of Nations } \\
\text { Group }\end{array}$ & EDN & EDN/ I-EDN & 1994 & 1999 & \\
\hline $\begin{array}{l}\text { Union for a Europe of } \\
\text { Nations }\end{array}$ & UEN & & 1999 & 2009 & $\begin{array}{l}\text { Modified Version of EDN. } \\
\text { Dissolved in } 2009 \text { when } \\
\text { two largest national parties } \\
\text { migrated to other groups. }\end{array}$ \\
\hline $\begin{array}{l}\text { Identity, Tradition, } \\
\text { Sovereignty }\end{array}$ & ITS & & 2007 & 2007 & $\begin{array}{l}\text { Jan-Nov 2007. Forced } \\
\text { dissolution under EP party } \\
\text { formation rules when the } \\
\text { Greater Romania Party } \\
\text { withdrew from the group. }\end{array}$ \\
\hline European & ECR & & 2009 & Present & \\
\hline
\end{tabular}


PARTy Positions IN THE EP -- p29

\begin{tabular}{|l|l|l|l|l|l|}
\hline $\begin{array}{l}\text { Conservatives and } \\
\text { Reformists Group }\end{array}$ & & & & & \\
\hline $\begin{array}{l}\text { European of Freedom } \\
\text { and Democracy }\end{array}$ & EFD & & 2009 & Present & $\begin{array}{l}\text { Largely made up of } \\
\text { elements of iD and some } \\
\text { former members of UEN }\end{array}$ \\
\hline $\begin{array}{l}\text { Technical Group for the } \\
\text { Defence of Independent } \\
\text { Groups and Members }\end{array}$ & CDI & I & 1979 & 1984 & Technical Group \\
\hline $\begin{array}{l}\text { Technical Group of } \\
\text { Independent Members }\end{array}$ & TDI & & 1999 & 2001 & $\begin{array}{l}\text { Dissolved as Court of First } \\
\text { Instance uphold ECJ ruling } \\
\text { that groups with no } \\
\text { coherent policy agenda are } \\
\text { not permitted. }\end{array}$ \\
\hline
\end{tabular}

